\title{
TOWARDS A FRAMEWORK FOR CLOSER UNIVERSITY-INDUSTRY COLLABORATION IN EDUCATING BUILT ENVIRONMENT PROFESSIONALS
}

\author{
Emlyn WITT ${ }^{1}$, Irene LILL ${ }^{2} \bowtie$, Chamindi MALALGODA ${ }^{3}$, Mohan SIRIWARDENA ${ }^{4}$, \\ Menaha THAYAPARAN ${ }^{5}$, Dilanthi AMARATUNGA ${ }^{6}$ and Arturas KAKLAUSKAS 7 \\ ${ }^{1}$ Department of Building Production, Tallinn University of Technology, Ehitajate St. 5, \\ EE-19086 Tallinn, Estonia \\ E-mail: emlyn.witt@ttu.ee \\ ${ }^{2}$ Department of Building Production, Tallinn University of Technology, Ehitajate St. 5, \\ EE-19086 Tallinn, Estonia \\ E-mail: irene.lill@ttu.ee \\ ${ }^{3}$ School of the Built Environment, University of Salford, The Cresent, Salford, M5 4WT, \\ United Kingdom \\ E-mail: C.I.Malalgoda@edu.salford.ac.uk \\ ${ }^{4}$ School of the Built Environment, University of Salford, The Cresent, Salford, M5 4WT, \\ United Kingdom \\ E-mail: M.L.Siriwardena@salford.ac.uk \\ ${ }^{5}$ School of the Built Environment, University of Salford, The Cresent, Salford, M5 4WT, \\ United Kingdom \\ E-mail: M.Thayaparan@salford.ac.uk \\ ${ }^{6}$ School of the Built Environment, University of Salford, The Cresent, Salford, M5 4WT, \\ United Kingdom \\ E-mail: R.D.G.Amaratunga@salford.ac.uk \\ ${ }^{7}$ Department of Construction Economics and Property Management, Vilnius Gediminas \\ Technical University, Sauletekio al. 11, LT-10223 Vilnius, Lithuania \\ E-mail: arturas.kaklauskas@vgtu.lt
}

Received 3 December 2011; accepted 25 October 2012

\begin{abstract}
Recent reports suggest that even the current industry skills needs are not being adequately met with graduate capabilities falling short of industry expectations. If higher education institutions (HEIs) are to respond effectively to the current and future challenges, a robust conceptual appreciation of the education-industry skills context is required in order to support recommendations and, ultimately, interventions. A conceptual framework aimed at addressing the 'mismatch' between the skills requirements of industry and the competences of graduates in the built environment sector was derived. A series of surveys was undertaken on the basis of the derived framework. It was intended that the findings from the surveys would enable the framework to be refined and validated. However, some of the findings suggest that the originally derived conceptual framework does not adequately represent the complexity of the professional learning context and it is not feasible to refine it. This paper describes the conceptual framework which was derived, highlights selected findings from surveys which indicate its inadequacy and then draws on the contemporary literature of higher education futures to discuss the implications for a more representative framework. Recommendations for a closer representation of the education-industry context and for further research directions are made.
\end{abstract}


KEYWORDS: Built environment; Lifelong learning; Higher education reform; Universityindustry collaboration; Skills mismatch

REFERENCE to this paper should be made as follows: Witt, E., Lill, I., Malalgoda, C., Siriwardena, M., Thayaparan, M., Amaratunga, D. and Kaklauskas, A. (2013) Towards a framework for closer university-industry collaboration in educating built environment professionals, International Journal of Strategic Property Management, 17(2), pp. 114-132.

\section{INTRODUCTION}

"Strategic" refers to "the identification of longterm or overall aims and interests and the means of achieving them" (Oxford Dictionaries, 2010). In terms of resolving the long-term and overall issues facing the property management field, few could be considered more strategic than the education of the professionals responsible for the built environment.

Nearly half a century ago, Peter Drucker noted in his book The Age of Discontinuity: Guidelines to Our Changing Society that the economy of goods was transforming into a knowledge economy (Drucker, 1969). Now, according to Melnikas (2010), this 'knowledge society' is viewed both as the "most important assumption" and "the main way to solve" the majority of the world's current social, economic and technological problems. In practical terms, capacities for information and knowledge generation, storage and transmission have increased vastly and the nature of work is being correspondingly transformed. Occupations are becoming associated less with industrial production and more with knowledge and information so that the economic primacy of the factory is being superseded by that of the laboratory or studio (Grubb and Lazerson, 2005; Hershock, 2012). In the emerging knowledge society, the role of higher education institutions (HEIs) is a matter of considerable debate. On the one hand, being at the forefront of knowledge production and its transmission (primarily to their students, the future 'knowledge workers' for industry), they are key enablers of the knowledge society. On the other hand, the increasing relevance of knowledge requires them to reform and the information and communications revolution has reduced their monopoly on knowledge creation, storage and dissemination (Stukalina, 2010; James, 2012). Hershock (2012) highlights the irony wherein the increasing speed with which new knowledge is being created serves to shorten the useful lifetime of existing knowledge and notes that HEIs must now reposition themselves in relation to the global flows of goods, services, people, ideas and ideals.

With the context of higher education changing, Korhonen-Yrjänheikki et al. (2007) note clear associated trends including:

- a remarkable rise in the need for continuing education;

- a closer integration of studies with working life;

- greater flexibility and a wider choice of study options and ways of learning.

In addition to these, James (2012) suggests that a shift in emphasis has occured:

- from mode 1 to mode 2 knowledge generation in Gibbons' terms (i.e. from discipline-based to problem-based knowledge, refer to Gibbons, 1997);

- from traditional, disciplinary studies to interdisciplinary studies;

- from acquiring contemporary knowledge to acquiring skills for independent lifelong learning; and,

- towards learning in the workplace.

The increasing referencing of higher education to the world of work is obvious yet it raises questions regarding the teaching function of HEIs - often characterized as a debate 
between 'liberal' and 'vocational' conceptions of higher education. The 'liberal' argument denies the narrow utilitarian presumptions that employment and work (in their current forms) are intrinsically good and that higher education should be subservient to the demands of the economic system and aimed at satisfying market needs (Tarrant I. and Tarrant J., 2004). The 'vocationalist' standpoint, in contrast, accepts the legitimacy of economic aims for education (Winch, 2002). However, neither extreme position is convincingly defensible since few would limit the scope of higher education to satisfaction of market needs nor could the employment aspirations of most students be ignored in favour of their intellectual, civic and moral development. Grubb and Lazerson (2005) offer a moderated vocationalist perspective where they note and accept a general historical trend towards vocationalism and away from liberal higher education values. Yet they differentiate the 'professionalism' they advocate from 'narrow vocationalism' which they deplore for impoverishing the intellectual and civic roles that higher education can play and for undermining genuine occupational preparation. They suggest that vocationalism of higher education understood in this broad sense provides its own avenues back to liberal education through, for example, the study of professions and the social, technological, ethical and philosophical issues which affect them.

In relation to the education of built environment professionals, most of whom would identify themselves as belonging to specific and historically recognised 'professions' (architects, engineers, surveyors, etc.), the vocationalist conception of Grubb and Lazerson (2005) outlined above is unlikely to differ greatly from that which most HEIs offer in their built environment-related study programmes. Yet there remains the problem of alignment, the widening gap between higher education outcomes and market needs and the criticism, mostly from industry and the political establishment, that higher education has failed to respond and adapt adequately to the economic changes of the past half-century (Hershock, 2012; Neubauer, 2012b; Kaklauskas et al., 2012).

The literature offers alternative perspectives on the resolution of the alignment problem which could be characterized as following a general education (i.e. focusing on theory and knowledge) or a 'skills approach' (i.e. providing students with specific skills for their future occupations). Pascail (2006), in arguing against a skills approach suggests that, for HEI graduates to be intellectually and professionally flexible, HEIs should focus rather upon instilling in them a 'general capacity' than focusing on the supposed characteristics of specific occupations. Alternatively, HEIs could seek to more directly address specific skills requirements and attempt to reduce the 'mismatch' between graduate skills and labour market skills requirements.

This paper reports research in which an initial conceptual framework inspired by a vocationalist and skills approach perspective on higher education provision and specifically aimed at addressing the perceived 'mismatch' was derived. A series of surveys were designed on the basis of the conceptual framework with the intention that their findings would enable refining and validating the framework. Section 2 of the paper describes in detail the derivation of the initial conceptual framework and research methodology as well as the rationale behind the choice of stakeholders and the design of survey questions.

However, some of the findings from the surveys appear to call into question the validity of elements of the initially derived conceptual framework and suggest that the context is considerably more complex than the framework implies. These selected findings are presented in Section 3.

Having identified the shortcomings of the initial conceptual framework, these are dis- 
cussed (in Section 4) in light of the contemporary literature on higher education futures in order to derive implications for a more representative conception of the higher education - industry context. Concluding remarks and recommendations follow in Section 5.

\section{DERIVATION OF THE INITIAL CONCEPTUAL FRAMEWORK AND RESEARCH APPROACH}

\subsection{The rationale for the BELLCURVE project}

Amaratunga et al. (2010) note the importance of investigating how HEIs can be modernised so as to provide the requisite skills and knowledge to the built environment sector in an efficient and effective manner. In this context, the consideration of 'student engagement' as a continuous, through-life process rather than the traditional, temporary association limited by course duration is appropriate. This throughlife studentship defines the essence of the new, innovative "lifelong university" concept, where learners' acquisition and development of skills and knowledge in response to changing industrial needs occurs on a continuous basis.

HEIs will not become innovative and responsive to change unless they have real autonomy and accountability. It appears then, that reform in governance systems based on strategic priorities to respond to labour market needs effectively while promoting the lifelong learning agenda may be in order and this suggests research aimed at higher education governance reform with a particular focus on lifelong learning.

In order to contend with the issues associated with the mismatch between graduate skills and labour market requirements and its impact on graduate unemployment and employer dissatisfaction in the built environment sector, a research project has been initiated.
The Built Environment Lifelong Learning Challenging University Responses to Vocational Education (BELLCURVE) is a European Commission funded research project currently being conducted at the School of the Built Environment, University of Salford, UK, in partnership with the Department of Construction Economics and Property Management, Vilnius Gediminas Technical University, Lithuania and the Department of Building Production, Tallinn University of Technology, Estonia.

The objectives of this project are:

- to develop a framework for HEI's to promote the Lifelong University concept in capturing and responding to labour market skill needs in the built environment;

- to refine, test and validate the developed framework;

- to provide recommendations on governance reform for HEIs to become 'continuing education centres' for graduates in responding to labour market skill needs.

\subsection{A theoretical framework for skills capture and response}

The Lifelong University as proposed in this research project is aimed at capturing labour market skills needs from the built environment field and responding to them by supplying the corresponding knowledge and skills. The BELLCURVE project contributes to this broader concept by developing a framework to capture and respond to the skills requirements with particular attention paid to governance reform. The following section explains the overall process envisaged for the development, refinement and validation of the framework. Firstly, conceptual aspects, where the initial conceptual framework developed for this project is presented with the variables and the relationships between variables identified within the framework. Secondly, the methodological aspects of developing the BELLCURVE framework are discussed. 


\section{Conceptual aspects}

"A conceptual framework explains, either graphically or in narrative form, the main things to be studied - the key factors, constructs or variables - and the presumed relationships among them" (Miles and Hurberman, 1994). The major variables involved in the development of the BELLCURVE conceptual framework are, labour market skills requirements; built environment; higher education; and lifelong learning. Figure 1 illustrates the initial conceptual framework.

When assessing the relationships between these variables, a key research problem was identified pertaining to the process of capturing skills requirements and HEIs appropriately responding to them. The principal components of HEIs which could be in need of reform were identified as Governance (G), Funding (F), and Curriculum (C) (European Commission, 2010). These three components are considered when framing the HEI in the conceptual framework. However, in investigating this problem, the BELLCURVE project concentrates on the governance component.

The main focus of this research is thus on governance reform where it aims to minimise the mismatch identified between the 'skills demand' and 'skills supply'. In this regard, three major elements of an initial framework were identified: capturing skills need ('demand'), responding to the skills needs ('supply') and HEI Governance reform (as shown in Figure 1). Key issues associated with these 3 elements were then analysed in order to address the identified problem.

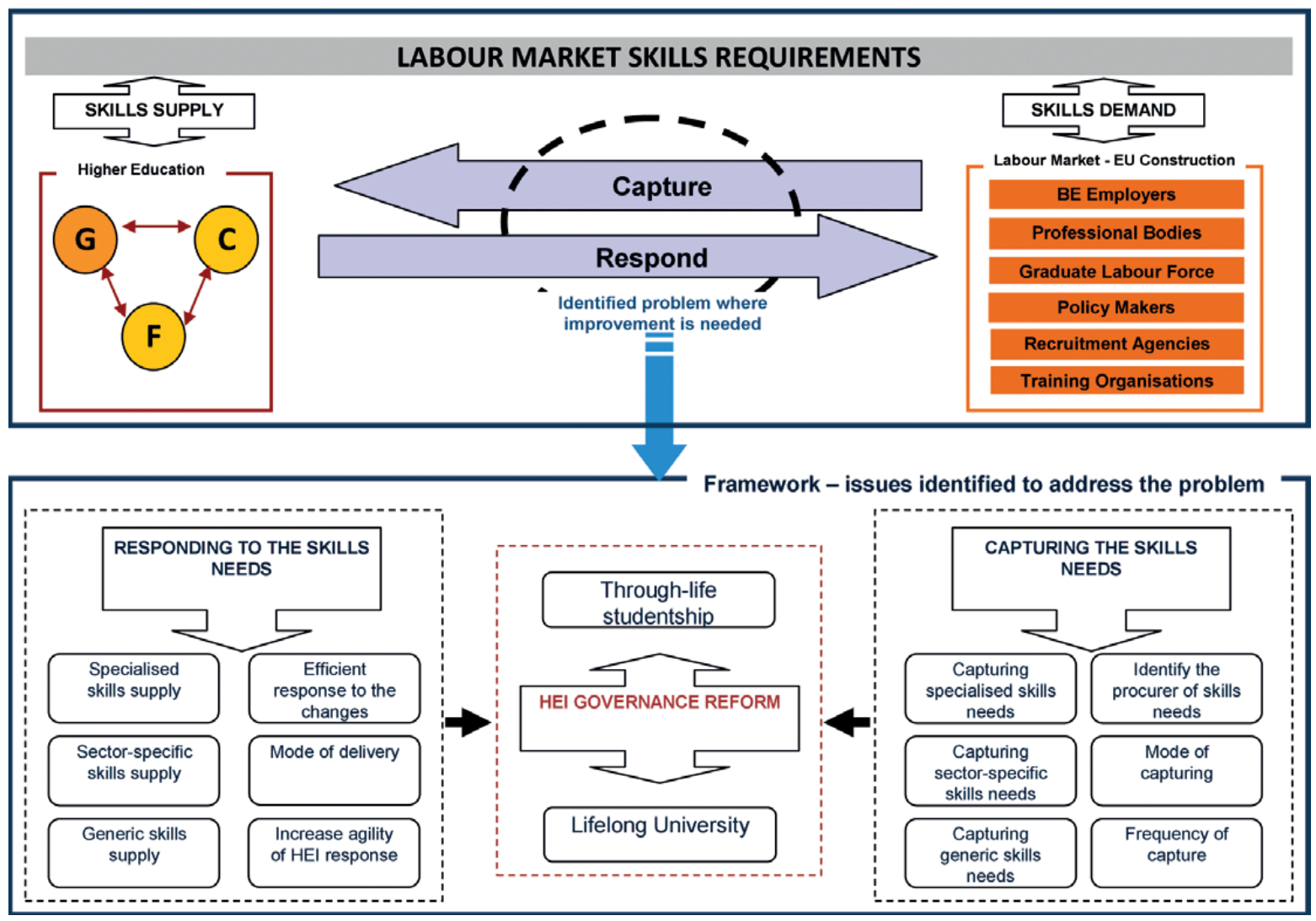

Figure 1. Initial conceptual framework 
The initial BELLCURVE framework (above) graphically depicts the envisaged impact of HEI governance reform in reducing the gap between capturing and responding to the skills needs. It conceives of 'skills capture' as a demand side issue and of 'skills response' as a supply side issue. Moreover, the labour market skills requirements (or the demand) are presented as created and/or reported by built environment employers, professional bodies, the graduate labour force, policy makers, recruitment agencies and training organisations. On the other hand, responding to skills needs is considered through supply of education and lifelong learning by HEIs. The research project set out to investigate the ways in which HEIs can be more responsive to labour market skills requirements and the framework reflects the initial premise that enabling HEI governance reform will ultimately support the concept of 'lifelong university'.

\section{Methodological aspects}

Research methodology refers to the overall approach to a problem which could be put into practice in a research process, from the theoretical underpinning to the collection and analysis of data (Remenyi et al., 1998; Collis and Hussey, 2003). There are many factors which determine the most appropriate methodology. The topics to be researched and the specific research questions are the primary drivers in the choice of methodology (Remenyi et al., 1998). Simon (1996) states that a natural science is a body of knowledge about some class of things - objects or phenomena - in the world (nature or society) that describes and explains how they behave and interact with each other. A science of the artificial (also known as a design science), on the other hand, is a body of knowledge about artificial (man-made) objects and phenomena designed to meet certain

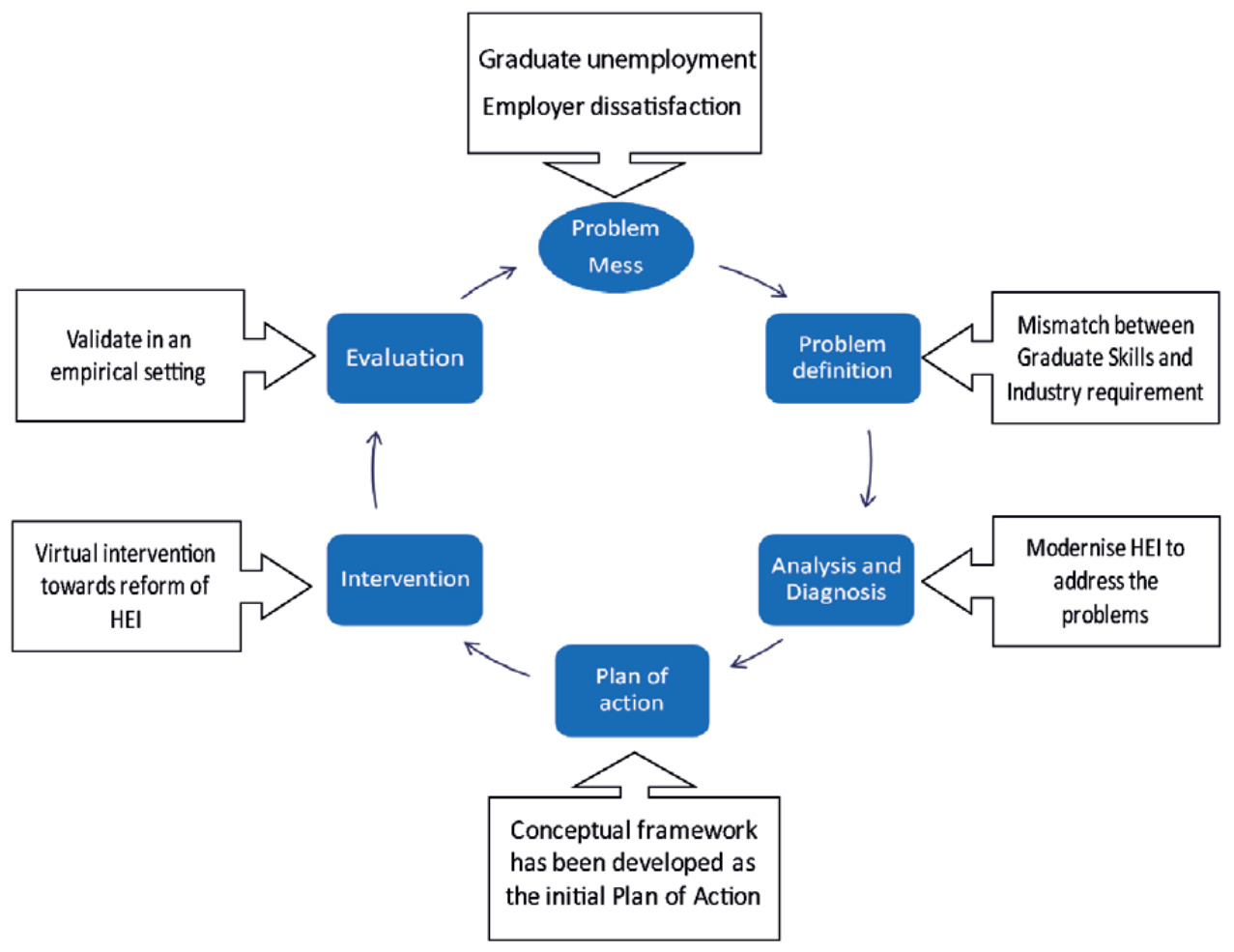

Figure 2. Basic process of the regulative cycle (adopted from Van Strien, 1997) 
desired goals. A design science approach (after Van Aken, 2004; 2005) was used as the overall research methodology in order to enable the developmental aspect of the BELLCURVE research project.

" $A$ science of the artificial is closely akin to a science of engineering; it is concerned with how things ought to be, in order to attain goals and to function. The core of that science would be provided by a science of design, a body of intellectually tough, analytic, partially formalizable, partially empirical, teachable doctrine about the design process" (Simon, 1996). Vaishnavi and Kuechler (2004) state that research can be very generally defined as an activity that contributes to the understanding of a phenomenon, and in the case of design science research, all or part of the phenomenon may be created as opposed to naturally occurring. Koskela (2008) provides an argument that the construction and, therefore, property management discipline may usefully be positioned within a design science framework.

The diagram in Figure 2 illustrates the methodology adopted to develop and refine the BELLCURVE framework. It shows the basic process of the regulative cycle adopted from Van Strien, 1997 (cited in Van Aken et al., 2007). Each stage of the regulative cycle is further elaborated in the context of the BELLCURVE research.

Each stage of the regulative cycle is matched with a stage of the BELLCURVE research project.

The BELLCURVE project methodology may be described as comprising 3 key stages (as illustrated in Figure 3):

1. Framework development. The initial framework (Figure 1) was developed from a review of the literature. It provides a basis for data collection which, in turn, allows for the refinement and validation (or otherwise) of the initial framework.

2. Framework refinement. Refinement of the initial framework was envisaged as achievable through surveys to elicit data from representatives of all stakeholder groups identified in the initial framework. The surveys being carried out in all 3 countries of the partner institutions (Estonia, Lithuania, UK).

3. Framework validation. To validate the refined framework, a case study strategy was chosen where the framework

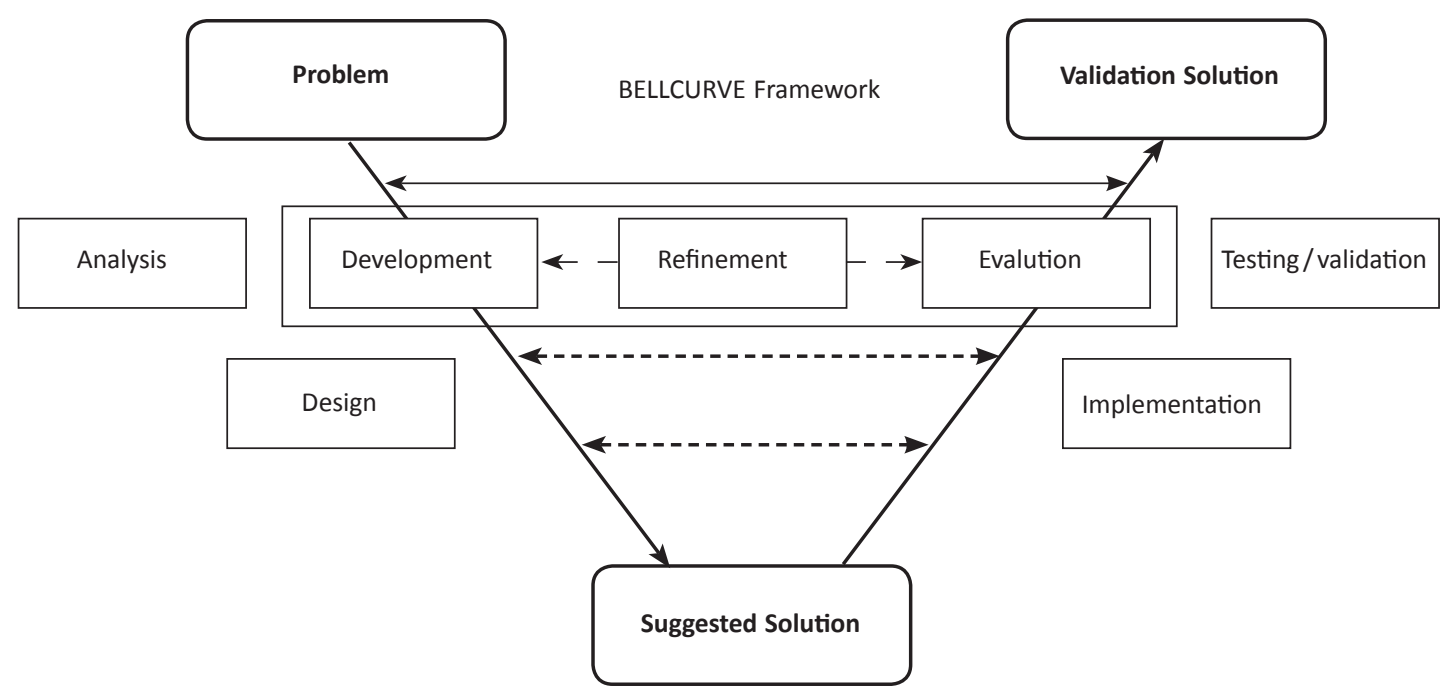

Figure 3. BELLCURVE framework development through a design science approach 
would be validated in a specific country and professional context on the basis of a case study. The professional areas selected were quantity surveying, disaster management, civil engineering, and construction management with the partner countries - UK, Lithuania and Estonia - providing the country contexts.

\subsection{Approach to Data Collection}

In order to rationalise the collection of empirical data relevant to refining the initial BELLCURVE framework, the stakeholders and the principal themes to be investigated were determined. The primary stakeholders and therefore survey respondent groups were identified as: HEIs, Policy Makers, Professional Bodies, Recruitment Agencies, Students, Graduates and Employers. In most cases, with slight variations between the 3 countries relating to their own specific national contexts, these primary stakeholders were further disaggregated into secondary stakeholders, for example, HEIs were subdivided into Leadership, Programme Directors, Lecturers, Academic Enterprise, Marketing, Careers \& Employability Unit and Researchers.

Two principal themes were identified to inform the design of questionnaires: 'skills matching' (relating to respondents' opinions on the existence, origins and nature of a 'mismatch') and 'lifelong learning' (regarding respondents' attitudes towards lifelong learning). These two themes were in turn broken down into a series of sub-themes as follows:

Skills matching:

- demand for skills;

- supply of skills;

- skills demand / supply / status comparisons.

Lifelong learning:

- enabling reforms;

- processes and mechanisms;

- challenges and barriers

and then into survey questions as appropriate for each specific (secondary) stakeholder.
The intention was that as many as possible of the stakeholders would be surveyed with respect to the two identified themes (i.e. the questions reflecting these themes) and parallel surveys would be carried out in each of the 3 project countries.

A mixed methods approach for the data collection and analysis was adopted in order to cater for the differing nature of respondent samples. Questionnaire surveys conducted among Estonian students and industry practitioners and Lithuanian students were quantitative and the number of respondents sufficient to justify meaningful statistical analyses of the findings. In the case of other stakeholders, surveys took the form of interviews, focus groups, workshops, formal and informal discussions and documentary reviews, all of which provided data of a qualitative nature.

For consideration of space, greater detail with regard to specific survey questions and the statistical analysis of data from individual surveys are not included here (it is, however published elsewhere, for example, Witt and Lill, 2012).

Data collection commenced in April 2011 and was brought to a close in October 2011. Not all the surveys had been responded to by this time but a sufficient body of data had been collected against which to consider the validity of the initial BELLCURVE framework.

This paper reports only those selected findings from 12 surveys which had been carried out by the end of October 2011 and which specifically pertain to the assumptions underlying the initial BELLCURVE framework.

\section{SELECTED FINDINGS}

\subsection{Details of the surveys from which the data are drawn}

With reference to the initial BELLCURVE framework (shown in Figure 1) it is convenient to consider the framework in parts as follows: 
Table 1. Details of the surveys from which selected findings are drawn

\begin{tabular}{|c|c|c|c|c|}
\hline$\#$ & Survey description & Country & Format & $\begin{array}{l}\# \\
\text { respondents }\end{array}$ \\
\hline Survey 1 & Disaster Management - Case Study & UK & Workshop & 15 \\
\hline Survey 2 & $\begin{array}{l}\text { Employers / Industry practitioners } \\
\text { survey }\end{array}$ & Estonia & $\begin{array}{l}\text { Web-based } \\
\text { questionnaire }\end{array}$ & 20 \\
\hline Survey 3 & Estonian Qualifications Authority & Estonia & E-mailed questions & 1 \\
\hline Survey 4 & Graduate survey & Estonia & $\begin{array}{l}\text { Web-based } \\
\text { questionnaire }\end{array}$ & 23 \\
\hline Survey 5 & HEI - leadership survey & Estonia & E-mailed questions & 1 \\
\hline Survey 6 & HEI - leadership survey & UK & $\begin{array}{l}\text { Semi-structured } \\
\text { interviews }\end{array}$ & 6 \\
\hline Survey 7 & HEI - lecturers survey & Estonia & E-mailed questions & 10 \\
\hline Survey 8 & Quantity Surveying - Case Study & UK & Workshop & 81 \\
\hline Survey 9 & $\begin{array}{l}\text { Recruitment agency - Unemployment } \\
\text { Insurance Fund }\end{array}$ & Estonia & E-mailed questions & 1 \\
\hline Survey 10 & Students survey & Estonia & $\begin{array}{l}\text { Paper-based } \\
\text { questionnaire }\end{array}$ & 123 \\
\hline Survey 11 & Students survey 1 - undergraduates, etc. & Lithuania & $\begin{array}{l}\text { Web-based } \\
\text { questionnaire }\end{array}$ & 113 \\
\hline Survey 12 & Students survey 2 - postgraduates, etc. & Lithuania & $\begin{array}{l}\text { Web-based } \\
\text { questionnaire }\end{array}$ & 28 \\
\hline
\end{tabular}

1. Perceptions of a mismatch between skills demand and skills supply.

2. The distinction between a 'supply side' and a 'demand side'.

3. The conception of capture - response in the context of skills.

4. Lifelong Learning (through-life studentships and the lifelong university concept).

5. HEI governance reform as a solution and to report selected survey findings which bear on these parts in order to comment on the initial framework.

As indicated in the preceding section, the data reported here are drawn from 12 surveys, details of these are given in Table 1.

Note that 2 case studies are included in Table 1. It was initially intended that the case studies would follow the refinement of the framework (the framework being refined on the basis of the surveys) in order to validate a refined framework. However, this process could not be fully followed in practice as the surveys took longer than anticipated. When the case studies were scheduled to commence, the surveys were not complete and 2 of the case studies which had been organized to coincide with conferences went ahead. These 2 case studies therefore referred to the initial framework rather than a refined framework. They have been included in this paper since their findings are relevant to a discussion of the initial framework.

\subsection{Findings}

The approach adopted in reporting the survey findings is as follows: the surveys were considered in turn to determine which of their questions / responses related to the selected components of the BELLCURVE framework as opposed to, for example, those questions / responses relating to specific skills and perceptions of the market demand for them. Key 
findings were then drawn from these questions / responses which provided insights into how representative of respondents' perceptions of the HEI - industry context the framework was. Owing to space limitations, only selected findings are presented in the tables in this section of the paper.

Perceptions of a mismatch between skills demand and skills supply
Table 2 summarizes the key findings pertaining to respondents' perceptions of a mismatch between skills demand and skills supply as well as those suggesting a reason for a mismatch.

The distinction between a 'supply side' and a 'demand side'

Table 3 presents a summary of respondents' opinions with regard to skills suppliers.

Table 2. Summarized findings relating to perceptions of a mismatch between skills demand and skills supply

Findings

Surveys (\#

from Table 1)

Perceptions of a skills mismatch

Both the Estonian HEI leadership and the Estonian Qualifications Authority reported that a mismatch existed between graduate skills and labour market skills requirements.

$91 \%$ of the Estonian graduates and $55 \%$ of the Estonian employers / industry practitioners surveyed considered that there was a mismatch between the skills and knowledge acquired at HEIs and those needed in industry.

Of the Lithuanian students surveyed, $48 \%$ considered that there was a difference between the skills and knowledge they were acquiring and those they needed to apply in industry compared to $52 \%$ who considered there was no difference. For Estonian students the proportions were $22 \%$ and $18 \%$ respectively (with the remaining $60 \%$ unsure or not responding to the question).

\section{Further insights into the notion of a skills mismatch}

$29 \%$ of Estonian students and 15\% of Estonian employers / industry practitioners surveyed considered that HEIs did not respond effectively to industry skills needs. 48\% of Lithuanian student respondents were of the opinion that HEIs did not have a proper system for responding to industry skills needs. $24 \%$ of the Estonian graduates surveyed were of the opinion that HEI responses were only partially effective.

The United Kingdom HEI leadership survey found that: "it is not practical to meet all the expectations from industry". Estonian HEI leadership did not consider that meeting current and future labour market skills needs was a major responsibility of HEIs and suggested that the extent to which skills acquired in studying at HEIs should correspond to labour market requirements was in the order of $75 \% .40 \%$ of the Estonian lecturers surveyed did not consider that meeting current and future labour market requirements was a major responsibility of HEIs.

The Estonian graduates surveyed considered it more likely that the missing skills were expected to be obtained from a source other than the HEI study programme than that missing skills had newly emerged or that the HEI curriculum was inadequate. The Estonian employers / industry practitioners surveyed rated a lack of engagement and collaboration between HEIs and industry to capture the skills requirements as being the primary reason for the mismatch.

Surveys 3 and 5

Surveys 2 and 4

Surveys 10 and 12

Surveys 2,4,10 and 12

Surveys 5,6 and 7

Surveys 2 and 4 
Table 3. Summarized findings relating to a distinction between a supply side and a demand side

\begin{tabular}{|c|c|}
\hline Findings & Surveys (\#) \\
\hline $\begin{array}{l}\text { Where they had perceived a need to obtain skills in the past, both the surveyed Estonian } \\
\text { graduates and those Estonian students who were employed reported that they had primarily } \\
\text { obtained the necessary skills by self-directed study. }\end{array}$ & $\begin{array}{l}\text { Surveys } 4 \text { and } \\
10\end{array}$ \\
\hline $\begin{array}{l}\text { The Estonian graduates surveyed reported that, when they received training it was most } \\
\text { frequently in the form of work-based learning. When they attended short courses, these were } \\
\text { most often organized by their company and rarely or never by an HEI. The Estonian students } \\
\text { surveyed who reported that they were employed, similarly noted that regular training in the } \\
\text { form of short courses was more likely to be provided by their companies, professional bodies or } \\
\text { private training firms than by HEIs. Asked what forms of training their employees undergo, } \\
\text { responding Estonian employers / industry practitioners indicated that work-based learning } \\
\text { or training organized by their companies, professional bodies or training firms were all more } \\
\text { common than training provided by HEIs. }\end{array}$ & $\begin{array}{l}\text { Surveys } 2,4 \\
\text { and } 10\end{array}$ \\
\hline $\begin{array}{l}\text { The majority of responding Estonian graduates (91\%) and of responding Estonian students } \\
(67 \%) \text { expected their employers (or future employers) to provide any skills which were not } \\
\text { adequately covered in their HEI course. }\end{array}$ & $\begin{array}{l}\text { Surveys } 4 \text { and } \\
10\end{array}$ \\
\hline $\begin{array}{l}\text { The Estonian Qualifications Authority noted that: "most of the professional standards are } \\
\text { based on competences gained or improved through work experience. In that sense awarding } \\
\text { of professional qualifications is most often based on recognition of prior learning, particularly } \\
\text { at work". The United Kingdom HEI leadership survey indicated that HEIs should produce } \\
\text { professionals who are eligible to get employed and able to learn through experience. }\end{array}$ & $\begin{array}{l}\text { Surveys } 3 \\
\text { and } 6\end{array}$ \\
\hline $\begin{array}{l}\text { Both the Disaster Management and the Quantity Surveying case studies found that HEIs } \\
\text { were currently one among several sources of skills supply available to practitioners. }\end{array}$ & $\begin{array}{l}\text { Surveys } 1 \\
\text { and } 8\end{array}$ \\
\hline
\end{tabular}

Table 4. Summarized findings relating to the conception of capture - response in the context of skills

\begin{tabular}{ll}
\hline Findings & Surveys (\#) \\
\hline $\begin{array}{l}\text { The UK HEI leadership survey found that industry needs should be considered when } \\
\text { responding to skills demands but expectations vary drastically from self-employed to small / } \\
\text { medium scale to large scale organisations. Similarly, according to the response of the Estonian }\end{array}$ & $\begin{array}{l}\text { Surveys } 6 \\
\text { and } 9\end{array}$ \\
$\begin{array}{l}\text { Unemployment Insurance Fund, skills requirements depend greatly on specific employers } \\
\text { needs. }\end{array}$ & \\
$\begin{array}{l}\text { Estonian student perceptions as to which particular skills are currently important in industry } \\
\begin{array}{l}\text { and which will become more important in the future vary considerably from respondent to } \\
\text { respondent. }\end{array}\end{array}$ \\
$\begin{array}{l}\text { The Estonian Qualifications Authority reported that it does adequately capture the knowledge } 10 \\
\text { and skills requirements of industry using functional mapping of each industrial sector and } \\
\text { developing professional standards for the corresponding job profiles. }\end{array}$ & Survey 3 \\
\hline
\end{tabular}

The conception of capture - response in the context of skills

The findings summarized in Table 4 high- light the diversity of skills demands and thus provide insight into the validity of a capture - response conceptualization. 
Table 5. Summarized findings relating to perceptions of lifelong learning

\begin{tabular}{|c|c|}
\hline Findings & Surveys (\#) \\
\hline $\begin{array}{l}\text { The Estonian Unemployment Insurance Fund noted that: "attitudes towards lifelong } \\
\text { learning are getting slowly better as it is realized more and more that being ready to undergo } \\
\text { additional training is necessary for maintaining a job". }\end{array}$ & Survey 9 \\
\hline $\begin{array}{l}\text { Responding Estonian employers / industry practitioners generally considered continuous } \\
\text { professional development as being necessary but they also indicated that available training } \\
\text { courses were not of sufficiently high quality. The absence of a systematic approach to } \\
\text { continuous professional development was also noted. In a similar vein, the Quantity } \\
\text { Surveying case study found a need for maintaining a knowledge resource for the profession. }\end{array}$ & $\begin{array}{l}\text { Surveys } 2 \\
\text { and } 8\end{array}$ \\
\hline $\begin{array}{l}\text { Both the Estonian graduates and students surveyed indicated that engaging in lifelong } \\
\text { learning was, on balance, becoming easier. }\end{array}$ & $\begin{array}{l}\text { Survey } 4 \text { and } \\
10\end{array}$ \\
\hline $\begin{array}{l}\text { The main incentives for and benefits from lifelong learning were perceived as being increased } \\
\text { confidence and knowledge and a greater diversity of employment opportunities (ahead } \\
\text { of improved earnings and promotion prospects) by the Estonian students and graduates } \\
\text { surveyed. }\end{array}$ & $\begin{array}{l}\text { Surveys } 4 \\
\text { and } 10\end{array}$ \\
\hline $\begin{array}{l}\text { HEIs were generally considered to be a highly regarded source of training by the Estonian } \\
\text { students and graduates surveyed. Responding Estonian employers / industry practitioners, } \\
\text { however, rated short courses from HEIs lower than those from private training firms. Both } \\
\text { Lithuanian and Estonian students expressed greater satisfaction than dissatisfaction with the } \\
\text { teaching and learning at their HEIs. It was further noted that lectures were both a preferred } \\
\text { mode of teaching and learning among Estonian student and graduate respondents and also } \\
\text { the mode primarily provided by the Estonian HEI lecturers surveyed. The Estonian employers } \\
\text { / industry practitioners and graduates surveyed both rated work-based learning as preferable } \\
\text { to attending lectures. }\end{array}$ & $\begin{array}{l}\text { Surveys } \\
2,4,7,10 \text { and } \\
11\end{array}$ \\
\hline $\begin{array}{l}\text { The response from the Estonian Qualifications Authority suggested that HEIs have } \\
\text { considerable opportunities to develop further study programmes to satisfy industry } \\
\text { requirements and expectations. }\end{array}$ & Survey 3 \\
\hline $\begin{array}{l}\text { The Estonian employers / industry practitioners and Estonian graduates surveyed indicated } \\
\text { that HEIs were less important sources of information regarding continuous professional } \\
\text { development than personal contacts, the internet, private training firms and professional } \\
\text { bodies. }\end{array}$ & $\begin{array}{l}\text { Surveys } 2 \\
\text { and } 4\end{array}$ \\
\hline $\begin{array}{l}\text { "Lack of time" was, by a considerable margin, the principal barrier to lifelong learning for the } \\
\text { Estonian students, graduates and employers / industry practitioners surveyed. Responding } \\
\text { Lithuanian students rated "lack of time" and "lack of funds" as equally most important. The } \\
\text { Estonian Unemployment Insurance Fund suggested "personal passivity" and "lack of financial } \\
\text { resources" were principal barriers together with local unavailability of training in some cases. }\end{array}$ & $\begin{array}{l}\text { Surveys } \\
2,4,9,10 \text { and } \\
12\end{array}$ \\
\hline
\end{tabular}

\section{Lifelong Learning and the Lifelong Univer- sity concept}

Table 5 presents a summary of findings regarding respondents' attitudes to lifelong learning.

HEI governance reform as a solution
Table 6 contains findings pertaining to the perceived need for HEI governance reform and opinions concerning the effectiveness of HEI study programmes. In addition, findings referring to the collaboration between HEIs and industry as well as between HEIs are included. 
Table 6. Summarized findings relating to HEI governance reform as a solution

\begin{tabular}{|c|c|}
\hline Findings & Surveys (\#) \\
\hline \multicolumn{2}{|l|}{ On the need for HEI Governance Reform } \\
\hline $\begin{array}{l}\text { The United Kingdom HEI leadership survey found that governance does not act as a barrier } \\
\text { for the HEIs to respond to the labour market skills needs. The Estonian HEI leadership survey } \\
\text { found that while governance reform to make HEIs more responsive was possible, it was not } \\
\text { necessary. The responding Estonian lecturers concurred that greater flexibility for study } \\
\text { programme amendments was not called for. }\end{array}$ & $\begin{array}{l}\text { Surveys } 5,6 \\
\text { and } 7\end{array}$ \\
\hline $\begin{array}{l}\text { Both the United Kingdom and the Estonian HEI leadership surveys found only potential } \\
\text { disadvantages (quality assurance problems and institutional stability issues respectively) in } \\
\text { reforming HEI governance for greater flexibility. }\end{array}$ & $\begin{array}{l}\text { Surveys } 5 \\
\text { and } 6\end{array}$ \\
\hline \multicolumn{2}{|l|}{ Support for closer HEI - industry collaboration } \\
\hline $\begin{array}{l}\text { Explicit support for closer collaboration between HEIs and industry was evident in the United } \\
\text { Kingdom HEI leadership survey, the Quantity Surveying case study, the Lithuanian students } \\
\text { survey and the Estonian surveys of HEI leadership, graduates, students and employers / } \\
\text { industry practitioners. }\end{array}$ & $\begin{array}{l}\text { Surveys } 2 \text {, } \\
4,5,6,8,10 \\
\text { and } 11\end{array}$ \\
\hline $\begin{array}{l}\text { The Estonian employers / industry practitioners surveyed indicated some willingness to engage } \\
\text { more closely with HEIs. }\end{array}$ & Survey 2 \\
\hline \multicolumn{2}{|l|}{ Support for closer collaboration between HEIs } \\
\hline $\begin{array}{l}\text { The Quantity Surveying case study found that collaboration between HEIs would be of benefit } \\
\text { in an HEI response to lifelong learning }\end{array}$ & Survey 8 \\
\hline
\end{tabular}

\subsection{General limitations of the data and findings}

It is important to acknowledge here the limitations which apply to these findings. Firstly, they are dominated by findings from Estonian surveys. Secondly, data collection took place in different language contexts and with surveys (both survey questions and modes of survey) adapted to local conditions. In this way, no two surveys (conducted in different countries) were precisely equivalent and, consequently, country comparisons are not well supported.

However, neither of these limitations prevents the findings providing support for or highlighting the shortcomings of the BELLCURVE framework.

\subsection{Interpretation of the findings}

Consideration of the survey responses above gives rise to the following conception of the HEI - industry context vis-à-vis the derived conceptual framework:
Perceptions of a mismatch between skills supply and skills demand

The findings (in Tables 2-6) appear to support the notion that stakeholders do indeed perceive a mismatch or misalignment between the skills required in industry and those provided by HEIs. However, this mismatch was not perceived by respondents simply as a gap needing closing and it was not generally viewed as constituting a problem in itself. Respondents did not expect that HEIs would entirely fulfill industrial skills needs but, at the same time, they also indicated that HEIs did not respond adequately to industrial needs.

The distinction between a 'supply side' and a 'demand side'

The conception of a 'supply side' (the HEI position) and a 'demand side' (where all other stakeholders are located) is shown to be problematic in that the findings suggest that HEIs are not the monopoly supplier but rather one among several suppliers. Some or all of the other stakeholders also appear to be impor- 
tant skills suppliers. In fact, in terms of continuous professional development, HEIs were found to be less important suppliers than most of the other stakeholders with employers and the learners themselves being the major skills providers identified by respondents.

The findings also imply a link to the issue of a skills mismatch in that the HEI graduate was apparently envisaged as being in possession of a set of skills which did not amount to those of a fully developed professional (and in that sense was incomplete) but which was intended to be developed further (by a combination of providers) in the work place. This suggests considerable ambiguity regarding the precise nature of the 'mismatch'.

The conception of capture - response in the context of skills

The adopted conceptual framework assumed a linear process of first determining (or capturing) what skills are needed and then attempting to provide them (responding). The survey findings showed great variations between respondents' perceptions of skills needs suggesting that 'capturing' a generally appropriate set of needed skills presents a considerable challenge.

At a broad level of definition, however, the findings also suggest that these needs are definable in some sense with respect to particular professions.

Lifelong Learning and the Lifelong University concept

The survey findings indicate that respondents consider the concept of lifelong learning to be increasingly accepted and supported by employers and individuals alike (at least with regard to the university-level educated individuals to which the surveys refer). In addition, the responses indicate that HEIs are highly regarded providers and therefore apparently well-placed to capitalize on the considerable opportunities to expand their educational offerings to satisfy lifelong learning needs.

The primary barrier to participation in further training perceived by respondents is not a lack of available study programmes or training courses, it is a lack of time.

\section{HEI governance reform as a solution}

The initial BELLCURVE framework was developed with the assumption that the implementation of the lifelong university concept would require greater flexibility and responsiveness from HEIs and that this agility would be achieved through governance reform. The surveys' findings suggest otherwise - that governance reform is not currently acting as a barrier and that too much flexibility would give rise to quality problems and could create instability for students and staff.

\section{DISCUSSION}

In this section, the apparent shortcomings of the initial BELLCURVE framework are discussed with reference to the contemporary literature on higher education futures in order to develop a deeper understanding of the HEI - industry alignment context.

\subsection{Perceptions of a mismatch between skills supply and skills demand}

Perceptions of a 'mismatch between skills supply and skills demand' relate to both the vocationalist / liberal education and the skills approach / general education debates. Firstly, in the general sense that an extreme liberal view would deny the validity of comparing industrial demand with higher education supply so that recognition of a mismatch in this sense requires that respondents relate to both the vocationalist and skills approach perspectives. Secondly, at a greater level of detail, there are potential discrepancies between conceptions of skills when these are framed in terms of a skills approach and in terms of a general education perspective and these differences could obscure the nature of any perceived 'gaps'.

This suggests considerable ambiguity regarding what constitutes a 'mismatch' and a range of possible interpretations for the conception of an ideally 'skilled' graduate from 'one who is in possession of all the skills they require to carry out their (current and future) work' to 'one who is in possession of adequate skills to enable the efficient acquisition of all the requisite skills to carry out the work'. 
While what is meant by "skills mismatch" is ambiguous, the question "Is there a skills mismatch?" should probably always be answered in the affirmative since a perfect fit is exceedingly unlikely regardless of what it means. Essentially, it is rather the truism that HEI study programmes can be improved that provides a basis for positive action than the existence of a "skills mismatch". The question then is "How?"

The existence of a mismatch between education outcomes and market needs has been noted by many authors (including Grubb and Lazerson, 2005; Hershock, 2012; James, 2012; Neubauer, 2012b). Hershock (2012) argues that reading the expanding relevance and preparedness gap between what markets want and what higher education produces as a unilateral function of the failure of HEIs to respond adaptively is appealing but simplistic. He suggests that the progressive misalignment of higher education outcomes and market needs is rather a function of the degree to which market economies have been allowed to become increasingly autonomous and disembedded from society as a whole while higher education has remained more firmly embedded in and responsive to society's constitutive dynamics. He thus implies that resolving such a mismatch, even if it were possible, may not be in the interests of society. With regard to the practicality of closing the gap, an earlier paper by the same author (Hershock, 2010) noted that, with the ever accelerating rate of knowledge production and differentiation, the half-life of scientific and technical knowledge had been reduced to 18 months. With the assumption that this has been further compressed in the last two years, it is inconceivable that the temporal dislocation between 'demand' and 'supply' would be insignificant to the extent that the mismatch could be eliminated.

The survey findings largely support these insights - the mismatch was acknowledged by respondents but they did not expect HEIs to entirely fulfill market skills needs. In addition, a majority of respondents considered that HEIs were not responding adequately to industrial skills needs, suggesting that HEIs should respond to market needs and thus indicating the acceptance of the vocationalist perspective by most respondents.

If the initial BELLCURVE framework was too simply and narrowly vocationalist and reflecting a skills approach in suggesting that skills could be matched, the emerging position from a consideration of the survey findings in light of the contemporary literature would suggest that a more satisfactory representation of the alignment problem would require further development of the framework in terms of:

- the extent to which market needs can be met by higher education provision; and,

- how educational products relate to the fulfillment of market needs.

\subsection{The distinction between a 'supply side' and a 'demand side'}

As indicated in the introduction, the reduction of HEIs' monopoly on knowledge creation, storage and dissemination has been noted in the literature as a consequence of the information and communication revolution and coincides with the increasing importance of learning in the workplace (James, 2012). Markkula and Lappalainen (2009) report estimates that more than $80 \%$ of all learning will occur on the job rather than in higher education.

The survey findings which suggest that respondents see HEIs as being one type among several types of skills suppliers, including employers and learners themselves, appears to reinforce these positions. Such a dynamic context where 'suppliers' and 'demanders' are interchanging is incompatible with the linear assumption of a 'supply side' and 'demand side'.

Similar economics-inspired analogies are available in the higher education futures literature. For example Neubauer (2012a) uses the term 'knowledge suppliers' to describe new institutions, mainly in the private sector, establishing new forms of linking knowledge provision with those for whom their services are intended, i.e. 'knowledge consumers'. He defends his use of the economic analogy noting that the institutions to which he refers are primarily oriented around the vocational inten- 
tion and application of the curricula they offer and almost entirely dependent on tuition fees from paying 'knowledge consumers'.

It seems then, that the supply side / demand side conception in relation to education loses relevance when the types of educational institution under consideration broadens beyond those purely vocationally focused and / or when the knowledge / skills in question relate to anything beyond that which the supplier is providing.

\subsection{The conception of capture - response in the context of skills}

The survey findings suggest that, in the context of skills, capturing them presents a considerable challenge. The great diversity and rapidly changing nature of skills needs among individuals and firms is not easily resolvable and neither is it apparent whether specific skills for doing or enabling skills for skills acquisition are required.

To what extent HEIs should concentrate on providing graduates with a skill set (if that is indeed possible in itself - see below) which enables them to efficiently acquire specific skills as and when they are needed and to what extent should HEIs attempt to impart the specific (for doing work) skills themselves? The modern lifelong learning paradigm also raises the issue of who takes responsibility for such choices as, increasingly, employability risks are being transferred to the individual (Witt and Lill, 2010).

A further conceptual problem emerges here with regard to the initial framework - the differences or discrepancies between teaching / training, the intended products of the teaching / training, the knowledge, skills and attitudes which are definable in the form of professional standards and the skills which industry needs. In elucidating the effects of the emergence of the 'skills approach' on the training of engineers, Pascail (2006) expresses the skills part of the problem thus:

"Schools of higher education by definition cannot create skills (at least not in the way espoused by the skills approach within industry) because, need we remind you, skills are created, named and evaluated within a specific context associated with a chosen activity and linked to a given performance. A school by definition works outside this type of context (it is in fact one of its specificities). Schools ... cannot give students skills in the strictest sense, as that has always been the contextual domain of industry."

Unless this terminological and conceptual muddle is resolved, the usefulness of any conceptual framework will be limited.

Yet, at a broad level of definition, the survey findings suggest that respondents perceive skills needs to be definable in some sense with respect to particular professions. This certainly accords with the position of many professional associations who have long sought (and largely achieved) a vocationally oriented influence on the curricula of HEIs (Grubb and Lazerson, 2005). However, in light of the definitional issues raised above, it is not immediately apparent how closely this would accord with a process of skills capture and response.

\subsection{Lifelong Learning and the Lifelong University concept}

The survey finding that the primary barrier to participation in further learning perceived by respondents is a lack of time is not surprising given the dynamics of the knowledge society. If technology-based knowledge now has a halflife of 18 months or less, even constant and full-time learning may soon be insufficient to keep up! Fortunately, the half-life of knowledge for most built environment professionals would be somewhat longer, though it would still be shortening rapidly.

Technological developments provide scope for diverse and innovative modes of information, knowledge and skills acquisition which can reduce learning times and widen access, but, as Hershock points out, it is ironically the successes of science and technology and the massive expansion of knowledge creation and dissemination which are driving the alignment crisis and the shortening of the useful life of knowledge. He notes that: "Modeling and responding to contemporary global dynamics requires a shift of focus from linear causeeffect chains to nonlinear causal ecologies...the 
dynamics of action-reaction have given way to complex interaction." He further argues that these complex interactions "do not present us with problems to be solved, but rather with predicaments that must be resolved." (Hershock, 2012) If this argument is accepted, then it seems that beneath the definitional and oversimplification issues affecting the initial conceptual framework, its fundamental limitation is that it attempts to represent complex interactions with a linear model.

\subsection{HEI governance reform as a solution}

The initial BELLCURVE framework was developed with the assumption that the implementation of the lifelong university concept would require greater flexibility and responsiveness from HEIs and that this agility would be achieved through governance reform. Perhaps the most interesting finding from the surveys was the contrary suggestion that governance reform is not currently acting as a barrier and that too much flexibility would give rise to quality problems and could create instability for students and staff.

Accepting that the sample of HEIs of which respondents had experience was not selected to ensure representativeness with regard to, for example, governance reforms in European HEIs, so that it is quite possible that the HEIs referred to in these surveys did indeed have more enabling governance regimes than is typical for European or global HEIs, this finding suggests that efforts to make higher education more responsive to market needs may be better applied to initiatives other than governance reforms.

In addition, whereas the contemporary literature provides a largely uniform vision of HEIs needing to become more diverse, adaptive, responsive and enterprising (for example, James, 2012), Neubauer (2012b) argues that these changes are constantly underway but they tend to be occurring incrementally rather than by broad and dramatic reforms.

The most obvious alternative solution concept would be to explore the possibilities for closer collaboration between HEIs and industry. These more at an operational level (spe- cific professions, specific courses, or similar) where definitional and complexity issues may be more effectively dealt with than the overall, strategic level of higher education - industry interaction.

Grubb and Lazerson (2005) offer similar advice: "The constant complaints about university-based preparation drifting too far from the world of practice suggests [integrating] the concerns of practice more thoroughly into the professionalized university, through internships, co-operative education, and other forms of work-based learning."

Almost all the respondent groups surveyed made recommendations along these lines and, with the findings also indicating that there was willingness amongst employers to engage more closely with HEIs, this appears to be worthy of further investigation as a potentially more fruitful alternative to HEI governance reform.

\subsection{General conception of HEI-industry collaboration on skills}

The notion of industrial skills requirements as the primary driver for HEI provisions is suggestive of an institutional hierarchy where HEIs are subservient to industry and it neglects the role of HEIs as the source of technological innovation and economic development (Etzkowitz and Leydesdorff, 2000). In a sense, the initial BELLCURVE framework, by focusing on the part of the industry-HEI relationship which involves industrial skills needs being satisfied through HEI teaching, tends to ignore that part of the relationship which involves the interaction between academic research, technological innovation and industry. Neither should be considered in isolation - "teaching is the university's comparative advantage, especially when linked to research and economic development" (Etzkowitz and Leydesdorff, 2000).

Where industry's interests can be better served through improved teaching and longer term relationships between HEIs and their alumni (the lifelong university concept), so too can HEI teaching and research be enhanced by closer collaboration with industry. 


\section{CONCLUDING COMMENTS AND RECOMMENDATIONS}

The initial BELLCURVE framework was derived from European policy documentation and formed the basis of an investigation into a 'mismatch' between industrial skills needs and graduate competences in Estonia, Lithuania and the United Kingdom. The expectation was that HEI governance reforms would enable greater HEI flexibility in responding to industrial needs and thus contribute to addressing the skills mismatch. The intentions were to refine the initial framework on the basis of the survey findings and then validate the refined framework on the basis of case studies. However, the findings from the surveys read in conjunction with the contemporary higher education futures literature imply that the initial BELLCURVE framework is insufficiently representative of the HEI-industry context in that:

- it attempts to represent the complex interactions of a dynamic context involving numerous stakeholders with a simple, static, linear model in which:

- the conceptualization of the stakeholders does not reflect their multiple and varied roles;

- the issue of the alignment of higher education provision with industrial needs is represented as a linear matching problem where the extent to which higher education provision can meet industry expectations, the equivalence of 'education provisions' to 'skills needs' and their interactivity in time are undefined.

- the problems of terminology and definition - HEI teaching outputs are not of the same nature as the 'skills' that industry needs and different types of HEI have different roles in relation to industry skills needs - are fundamental to the initial framework and have not been resolved;

- the findings imply that HEI governance (in the HEIs represented) does not constitute a major barrier to improving alignment.
In order to achieve improvement in aligning HEI provisions with market needs, it seems that a sensible starting point would rather be in closer collaboration between HEIs and industry.

It is recommended to resolve the terminological and definitional issues regarding HEI teaching outputs and industrial skills needs and to develop a revised conceptual framework which better reflects the complexity of the HEI-industry context. Such a conceptual framework could then provide insight into how HEIs might adapt to improve the efficiency and effectiveness of their contribution to the built environment sector to better serve society.

\section{ACKNOWLEDGEMENT}

The BELLCURVE research project has been funded with support from the European Commission. This publication reflects the views only of the authors, and the Commission cannot be held responsible for any use which may be made of the information contained therein.

\section{REFERENCES}

Amaratunga, D., Pathirage, C. P., Kereminiyage, K. and Thayaparan, M. (2010) Advancement of built environment higher education through lifelong learning. In: Proceedings of International Research Conference on Sustainability in Built Environment, Colombo Sri Lanka, 18-19 June 2010, pp. 31-39.

Collis, J. and Hussey, R. (2003) Business research: A practical guide for undergraduate and postgraduate students. $2^{\text {nd }}$ ed. New York: Palgrave Macmillan.

Drucker, P. F. (1969) The age of discontinuity: Guidelines to our changing society. London: Heinemann.

Etzkowitz, H. and Leydesdorff, L. (2000) The dynamics of innovation: From National Systems and "Mode 2" to a Triple Helix of university-industry-government relations, Research Policy, 29(2), pp. 109-123. http:// dx.doi.org/10.1016/S0048-7333(99)00055-4

European Commission (2010) The higher education modernisation agenda. [Online] European Commission. Available at: http://ec.europa.eu/education/highereducation/doc1320_en.htm [accessed August 2010]

Grubb, W. N. and Lazerson, M. (2005) Vocationalism in higher education: The triumph of the education gospel, The Journal of Higher Education, 76(1), pp.1-26. http://dx.doi.org/10.1353/jhe.2005.0007

Hershock, P. (2012) Information and innovation in a global knowledge society: Implications for higher education. The emergent knowledge society and the future 
of higher education - Asian perspectives, edited by Neubauer, D. E. London: Routledge, pp. 7-25.

James, R. (2012) Aligning universities and higher education systems with the challenges of emergent knowledge economies, The emergent knowledge society and the future of higher education - Asian perspectives, Neubauer, D. E. (ed.) London: Routledge, pp. 41-54.

Kaklauskas, A., Daniūnas, A., Amaratunga, D., Urbonas, V., Lill, I. Gudauskas, R., D‘Amato, M., Trinkūnas, V. and Jackutè, I. (2012) Life cycle process model of a market-oriented and student centered higher education, International Journal of Strategic Property Management, 16(4), pp. 414-430. http://dx.doi.org/10.3846/1648715X.2012.750631

Korhonen-Yrjänheikki, K., Tukiainen, T. and Takala, M. (2007) New challenging approaches to engineering education: Enhancing university-industry co-operation, European Journal of Engineering Education, 32(2), pp. 167-179. http://dx.doi. org/10.1080/03043790601118697

Koskela, L. (2008) Which kind of science is construction management? In: Proceedings of the 16th Annual Conference of the International Group for Lean Construction, Manchester, pp. 51-60.

Markkula, M. and Lappalainen, P. (2009) New openings in university-industry cooperation: Aalto University as the forerunner of European university reform, European Journal of Engineering Education, 34(3), pp. 251-262. http://dx.doi. org/10.1080/03043790902902922

Melnikas, B. (2010) Sustainable development and creation of the knowledge economy: The new theoretical approach, Technological and Economic Development of Economy, 16(3), pp. 516-540. http://dx.doi. org/10.3846/tede.2010.32

Miles, M. B. and Hurberman, A. M. (1994) Qualitative data analysis. $2^{\text {nd }}$ ed. London: Sage Publications.

Neubauer, D. E. (2012a) Introduction. The emergent knowledge society and the future of higher education - Asian perspectives, Neubauer, D. E. (ed.) London: Routledge, pp. 1-6.

Neubauer, D. E. (2012b) The end of the university as we know it? The emergent knowledge society and the future of higher education - Asian perspectives, Neubauer, D. E. (ed.) London: Routledge, pp. 194-208.

Oxford Dictionaries (2010) "strategic" Oxford Dictionaries. April 2010. Oxford University Press. Available at: $<$ http://oxforddictionaries.com/definition/strategic $>$ [accessed 11 November 2011]

Pascail, L. (2006) The emergence of the skills approach in industry and its consequences for the training of engineers, European Journal of Engineering Education, 31(1), pp. 55-61. http://dx.doi. org/10.1080/03043790500428965
Remenyi, D., Williams, B., Money, A. and Swartz, E. (1998) Doing research in business and management: An introduction to process and method. London: Sage Publications.

Simon, H. A. (1996) The sciences of the artificial. $3^{\text {rd }}$ ed. Cambridge (MA): The M.I.T. Press.

Stukalina, Y. (2010) Using quality management procedures in education: Managing the learner-centered educational environment, Technological and Economic Development of Economy, 16(1), pp. 75-93. http://dx.doi.org/10.3846/tede.2010.05

Tarrant, I. and Tarrant, J. (2004) Satisfied fools: Using J. S. Mill's notion of utility to analyse the impact of vocationalism in education within a democratic society, Journal of Philosophy of Education, 38(1), pp. 107-120. http://dx.doi.org/10.1111/j.03098249.2004.00366.x

Vaishnavi, V. and Kuechler, B. (2004) Design research in information systems. [Online] Available at: http:// desrist.org/design-research-in-information-systems [accessed 11 April 2011]

Van Aken, J. E. (2004) Management research based on the paradigm of the design sciences: The quest for tested and grounded technological rules, Journal of Management Studies, 41(2), pp. 219-246. http://dx.doi. org/10.1111/j.1467-6486.2004.00430.x

Van Aken, J. E. (2005) Management research as a design science: Articulating the research products of mode 2 knowledge production in management, British Journal of Management, 16(1), pp. 19-36. http://dx.doi. org/10.1111/j.1467-8551.2005.00437.x

Van Aken, J. E., Berends, H. and Van der Bij, H. (2007) Problem solving in organisation: A methodological handbook for business students. Cambridge: Cambridge University Press.

Van Strien (1997) Towards a methodology of psychological practice: The regulative cycle, Theory and Psychology, 7(5), pp. 683-700. http://dx.doi. org/10.1177/0959354397075006

Winch, C. (2002) The economic aims of education, Journal of Philosophy of Education, 36(1), pp. 101-117. http://dx.doi.org/10.1111/1467-9752.00262

Witt, E. D. Q and Lill, I. (2010) The mismatch between graduate competences and market skills requirements in the construction sector - the Estonian situation. In: Proceedings of COBRA 2010, Paris, 2-3 September 2010.

Witt, E. and Lill, I. (2012) Lifelong learners in engineering education - students' perspectives, International Journal of Education and Information Technologies, 6(1), pp. 9-16. 